\title{
Urban agriculture, civil interfaces and moving beyond difference: the experiences of plot holders in Dublin and Belfast
}

\author{
Mary P. Corcoran* and Patricia C. Kettle \\ Department of Sociology, Maynooth University (National University of Ireland Maynooth), \\ Maynooth, Ireland
}

(Received 9 January 2014; accepted 15 March 2015)

\begin{abstract}
Recent literature suggests that a "shared politics of place" attained through joint activities fosters social integration and provides people with a means to practise co-operation [Baumann, G., 1996. Contesting culture: discourses of identity in multi-ethnic London. Cambridge: Cambridge University Press; Sanjek, R., 1998. The future of us all: race \& neighbourhood policies in New York City. Ithaca, NY: Cornell University Press; Sennett, R., 2012. Together: the rituals, pleasures and politics of cooperation. UK: Penguin]. Such a "shared politics of place" is most likely to occur in the context of public space conceptualised broadly as "the setting for everyday spatial behaviour of individuals and communities, emphasizing ordinary activities of citizens" [Lownsbrough, H. and Beunderman, J., 2007. Equally spaced? Public space and interaction between diverse communities. London: Demos, p. 8]. Here we explore one element of such public space - urban agriculture sites - with a view to identifying the extent to which a "shared politics of place" can be created and nurtured among the cultivating citizenry. The paper draws on data collected on allotment gardening sites in two urban contexts: Dublin (Ireland) and Belfast (Northern Ireland) over the period 2009-2013. We demonstrate the centrality of allotment cultivation to the generation of solidarity, mutuality and trust among participating citizens. Individuals engaging in allotment gardening in both Dublin and Belfast create and sustain civil interfaces - dismantling barriers, exchanging knowledge, challenging stereotypes, generating empathy and getting on with the business of simply getting on with their lives. The modus operandi of allotment gardening is predicated on a willingness to disregard social and ethno-national categorisations while on site. This is not to deny that such differences exist and persist, but allotments offer a "space of potential" where those differences are, at least for a time, rendered less salient.
\end{abstract}

Keywords: urban agriculture; politics of place; social class; ethno-national division; public space

If you live in a city with a million and half people, you can't be waving at everyone so you end up waving at no one .... . everyone's rushing around, they're all plugged in, and no-one has the time to stop and chat anymore. (Allotment gardener, Dublin, 2012)

\footnotetext{
*Corresponding author. Email: mary.corcoran@nuim.ie
} 


\section{Introduction}

Contemporary cities face a number of key challenges including economic (the global financial crisis and concomitant fiscal crisis confronting national governments and urban regimes) and social (the retrenchment of the welfare state, poverty gap and growing levels of obesity associated with more sedentary lifestyles). Cities are also becoming more diverse (significant levels of migration). Social exclusion and social polarisation are characteristic of many cities where "urban space, while it is functionally and economically shared, is socially segregated and culturally differentiated" (Robins 1993, p. 313). Against this backdrop research shows that public and voluntary bodies operating in the civil society sphere can play a crucial role in fostering better social relations, integration and social cohesion (Vertovec 2007). Recent literature suggests that a "shared politics of place" attained through joint activities which acknowledge difference and promote inclusion, foster social integration and provide people with a means to practise co-operation (Baumann 1996, Sanjek 1998, Eizenberg 2012, Sennett 2012). Such "a shared politics of place" is most likely to occur in the context of public space conceptualised broadly as "the setting for everyday spatial behaviour of individuals and communities, emphasizing ordinary activities of citizens" (Lownsbrough and Beunderman 2007, p. 8). Here we explore one element of such public space - urban agriculture (UA) sites - with a view to identifying the extent to which a "shared politics of place" can be created and nurtured among the cultivating citizenry.

This paper draws on data collected between 2009 and 2013 across a range of allotment gardening sites in two urban contexts: Dublin (Ireland) and Belfast (Northern Ireland). Allotment gardening in both cities was originally provided for under British legislation which has ensured their provision, maintenance and statutory legitimacy to the present day. The residualisation of UA was a marked trend in both cities during the twentieth century (although this was more so the case in Dublin than in Belfast). Nevertheless, there is evidence of a renewal of interest in UA demonstrated in rising demand among the citizenry for plots, increased provision by both municipalities and private operators and a growing awareness of the value of growing one's own among the urban citizenryat-large. Our aim is to identify what role UA can play in fomenting a shared politics of place and a basis for renewed social cohesion given both the general challenges faced by cities today and the specific challenges faced by Dublin and Belfast. This paper approaches UA as a particular and localised instance of a shared politics of place, and seeks to demonstrate UA's potential to generate civic and social dividends for participants. In this way, UA can be seen not simply as an environmental or ecological intervention in urban space. Rather we argue it is also a social process that contributes to nurturing inclusive and vibrant public space and public infrastructure in the contemporary city (Amin 2010).

\section{Towards a shared politics of place}

In this paper, we illuminate elements of the interactive order of everyday urban life focusing particularly on the cultivation practices of urban allotment holders. We are interested in the potential of urban allotments to help re-shape the politics of place at a time when cities are viewed as becoming ever more privatised, more polarised and more exclusionary (Punch 2005, Sennett 2005, Sassen 2013). We argue that such a re-shaping may occur through the process of social levelling on site. Key features of the allotment sites - their openness to all comers, their democratic structure and the low threshold of entry - position them closer to the public than the private realm. Furthermore, the kinds of social markers that 
have a taken-for-granted currency in everyday life are generally eschewed by plot holders. Identifying characteristics are parked at point of entry which allows for the creation of a different kind of politics of place. Class, status and ethno-religious identities are rendered less salient, as allotment holders invest their mental and physical labour in the care and cultivation of the land. The social levelling which results - albeit temporary and site specific indicates that urban agricultural initiatives constitute an important "space of potential" in the city.

Following Jacobs (1961), we approach cities as an ongoing work accomplished by those who live, work and socialise in them. In The death and life of great American cities, Jacobs argued that the nature of the city is best examined through its public realm, sidewalks, parks and neighbourhoods, all of which Jacobs viewed as crucial sites of civil interface. Furthermore, she contended that the well-being and liveability of a city are connected to levels of diversity. Jacobs understood diversity not so much as a characteristic of demography, but rather in terms of different kinds of economic functions, the mixing of diverse cultural groupings and tolerance of diverse cultural practices. Similarly, Sennett has described multi-functionality as the sine qua non for provoking "vivacity in public spaces" (2011, p. 395, Sennett 1970). Cities that lack a natural and casual public life (one that is serendipitously produced rather than engineered) are more likely to engender social isolation, or as Jacobs eloquently observed would "lack public acquaintanceship ... and no practice or ease in applying the most ordinary techniques of city public life at lowly levels" (1992, p. 65). Jacobs's somewhat utopian view of the city and its potential has been eclipsed in recent decades by a more dystopian view that has emphasised the deleterious impacts on cities of processes such as gentrification, privatisation, suburbanisation, deregulation and so on. Oldenburg (1989), for instance, highlights the disappearance of informal places in cities - so-called third places - that are important for maintaining civil society and democratic engagement. Third places he suggests are being replaced by non-places where individuals lose their individuality. To the degree that they relate to one another, they do so in purely functional and impersonal terms, as customers rather than citizens.

A counterargument has been advanced by Lownsbrough and Buenderman (2007) who, while acknowledging that some third places may be disappearing, point to the emergence of new types of public space in cities and neighbourhoods: formal and informal, public and semi-public, deliberate and spontaneous. They identify eight main types of "spaces of potential": exchange, productive, service provision, activity, democratic/participative, staged, in-between and virtual. These are not to be interpreted in a narrowly spatial sense: in practice many places will have elements that cut across more than one definition, since the category into which a space falls is dictated by the activity happening within it at different times. It is the central importance of trust and confidence from users in creating valuable public space that links these "spaces of potential". The elements of new public space include: capacity for multi-use, accessibility, legibility, clarity about the boundaries between public and private, local relevance, adaptability to people's diverse needs and desires, open-endedness and safety. In a similar vein, Eizenberg's (2012) study of community gardens in New York City reveals the possibility of re-envisioning "the commons" outside of a public-private dichotomy. Community gardens introduce new social, cultural and political practices that make possible alternative frameworks for social relations and social practices. Finally, Madden (2010) suggests that it is possible to move the analysis of public space beyond questions of inclusion and exclusion, and "toward an empirical examination of the powers, practices, institutions, and ideas which do the work of constituting the public" (2010, p. 191). We argue that the empirical investigation of allotment sites 
in two urban contexts - both with different histories and with different challenges - creates the possibility of re-framing a local politics of place. Specifically, we argue that allotment sites produce an inclusive and socially cohesive notion of the public. This is possible because of the creation of a shared politics of place - a commitment to cultivation that is premised on individual labour carried out in a common cause, mutually agreed tacit rules of engagement and tolerance of diversity. We suggest that allotments are a vivacious public space that foment social levelling and that afford the opportunity for mutual tolerance and respect to friend and stranger alike. Thus, they fulfil an important role associated with public urban life (Sennett 2011). Furthermore, allotment gardening, facilitated and supported by local municipalities, promotes a more public politics of place (open, accessible and traversed by all) which stands in contradistinction to a more privatised politics of place (evidenced in shopping malls, gated communities, policed public thoroughfares and so on). These themes are elucidated in more detail in the remainder of this paper.

\section{Researching UA: genesis and rationale for the current study}

Interest in UA nowadays predominantly focuses on its contribution to sustainability in cities of the developing world (Mougeot 2005, 2006). This is unsurprising as Tornaghi (2014) has observed that the engagement of citizens in the production of food in the Global North has been limited and marginalised. Cuba, for instance, has been widely recognised as a leading proponent of UA. According to Premat (2005) UA became particularly important in Cuba during the post-Soviet economic crisis, a consequence of which was greater food insecurity. Urban agricultural initiatives intensified in the post-1989 period. The success of Cuban organic agriculture heralds not just the application of new agricultural technology but the transformation of social and spatial relations on the land, (Clausen 2007). Clausen explains this in terms of a range of agricultural, labour and distributional practices that promote metabolic restoration rather than metabolic rift (the rupture of the ecological balance between humans and nature).

Research on UA has primarily focused on its contribution to urban biodiversity, sustainability and socio-economic development (Binns and Lynch 1998, Hampwaye et al. 2009). The literature, however, also highlights the direct benefits UA offers in terms of public health, cultural connection, human interaction and community development (Howard 1965, Crouch 1989, Smit and Nasr 1992, Moselle 1995). Studies on home-grown food in Toronto, for example, suggest that gardeners seem to value allotment gardening more for its social value than for its contribution to family subsistence (Kortright and Wakefield 2011). Other studies in the USA suggest that UA practices are an important means of selfexpression, help migrants maintain cultural identities, contribute to the enhancement of health and well-being, and constitute landscapes which cement relationships within communities (Warner 1987). Intercultural gardens have been identified in Germany as particular spaces that respond to the specific needs of immigrants. They afford access to an arena of social interaction that is outside of home and work environments and that promotes mutual respect between participants, (Moulin-Doos 2014). Such gardens eschew a patronising approach to the integration of immigrants and focus on engaging in joint activities which allow the urban citizenry in concert to give shape to their immediate environs, (Muller 2007). Karantasai (2011) refers to transcultural gardens as primarily collaborative spaces that enable migrants from rural backgrounds, in particular, to integrate into urban contexts.

The attraction of UA increasingly extends beyond the densely populated cities of the Global South to the cities of the Global North. In New York City, community gardens which date to the economic crisis of the 1970s are viewed as an instance of 
counter-hegemonic space that can arrest the decline of the commons implicit in the neoliberal political project, (Eizenberg 2012). For Eizenberg, community gardens represent a revival of the commons - the notion of space not as private property but as a resource that belongs to everybody and to nobody at the same time. Similarly, in her classic work on the urban public realm, Lofland (1973) defines public space as those areas of a city to which all persons enjoy legal access. They belong to no one and therefore to everyone. As such, they have the potential to generate an alternative framework for generating social relations and social practices. Tornaghi, in a recent critical review of UA research, argues that we still lack a systematic analysis of "the geography of urban food cultivation and its relations with the politics of space" $(2014$, p. 3$)$. She calls for an exploration of the meaning of UA initiatives in different urban contexts and, in particular, its role in addressing urban problems. This paper is intended to address the gap in the literature by focusing on two cities in the Global North, each of which has faced specific localised challenges the financialisation of urban space (Dublin) and the politicisation of urban space (Belfast). We provide evidence to show that in both cities, UA initiatives move beyond processes of financialisation and politicisation to accommodate the urban citizenry in shared-in-common places. The study is situated mostly in two locales - Dublin and Belfast - but set against a wider comparative analysis of UA across Europe as part of an EU COST Action network. ${ }^{1}$

Dublin city flourished economically during the early years of the twenty-first century. Incomes and spending power rose in Ireland, generating high levels of consumer exuberance among large swathes of the populace. This was evidenced in the exorbitant prices paid for modest homes, an increase in international travel and dramatic levels of consumer spending (dependent on credit rather than savings) generally. Since the economic collapse of 2008, which ultimately resulted in the IMF/EU bailout of 2010, austerity policies have resulted in significant drops in income, higher unemployment levels and a contraction in consumer spending, (Rigney 2012). During the same time period, there has been a demonstrable rise in UA practices in the city of Dublin, reliant on both public and private provision of allotments in the city and on its perimeter. This rising interest has been partly driven by a flourishing civil society sector committed to promoting sustainable forms of production, greater food awareness, better strategies for health and well-being promotion and food sovereignty. The media has also played an important role reporting on this "ecological shift" among the citizenry. Allotment holders now constitute a diverse population. No longer dominated by older, working class males, plots are now tended by working class and middle class women and men, immigrants and community groups and advocacy groups catering for clients with special needs. We are interested in exploring what role UA can play in promoting social solidarity, mutuality and trust and a shared politics of place within and across class groupings under conditions of austerity.

Despite the political resolution of the conflict in Northern Ireland, Belfast remains a city divided along religious and ethno-national lines. The sectarian inscriptions on the landscape continually reinforce both the idea and the reality of a divided city. As O' Dowd and McKnight observe: “'Protestant' and 'Catholic' remain far more widely accepted labels for citizens in Northern Ireland, than national (British, Irish, Northern Irish) or political (unionist, nationalist, republican) labels" (2013, p. 371). Furthermore they note that the physical environment of the city and its morphology - in terms of, for instance, the range and distribution of places of worship - demonstrates the continued salience of religion in everyday urban life. Violent division is effectively inscribed in the cityscape, through periodic protests, riots and paramilitary campaigns aimed at disrupting the normalisation process underway in the wake of the political resolution of the conflict. O'Dowd and 
McKnight note that although there are examples of alternative forms of social solidarity and social mobilisation that engage in bridge-building across the community divide in the city, these are less frequent, less visible and are less embedded in either civil society or the state. Moreover, not only religion but other contested concepts such as "space", "place" and "territory" are embedded in extremely complex ways in the material fabric of Belfast, (O’Dowd and Komarova 2009). Belfast is characterised by a long history and memory of segregation, territoriality, street rioting, marches, parades and commemorative activities. To some degree the publicness of the city has been re-configured as a theatre of action in which two ethno-national traditions are publically performed and played out. Clergy and others involved in faith-based community initiatives strive to contain the legacy of violence and to identify pathways for moving forward into a fully "post-conflict" society.

This raises the question of what other avenues may be available that can allow urban dwellers in Belfast to engage in a shared politics of place despite the history of sectarianism and residual ethno-national conflict. Bryan (2009) examines the development of civic events such as the Lord Mayor's Show and the development of the St. Patrick's Day festival as examples of inchoate sharing of public space in Belfast. Crucially, both initiatives have the moral and financial support of the municipality. He sees in these kinds of initiatives the possibility of the development of a civic culture that can ameliorate the territorial and ethnonational differences that frame identity construction in the city. In the same way, we contend that UA sites might be classified as non-contested space and as such also have the potential to become shared-in-common places in the city. Given the significant policy and political commitments to social cohesion and social inclusion in both Ireland and Northern Ireland, there is, we argue, "a need for a more thorough analysis of the potential for different types of public space to support positive interactions between different social, economic and ethnic groups" (Lownsbrough and Beunderman 2007, p. 10).

The study employs multi-sited ethnographic methods using methods of triangulation (semi-structured interviews, participant observation and visual analysis). Field work was conducted in two phases. The first phase was conducted in 2009 and involved photographing six allotment sites in Dublin and conducting interviews with plot holders and advocates for UA. Eighteen interviews and a field diary were completed during this phase. The second phase of fieldwork was conducted between 2011 and 2013 across seven sites in Dublin and six sites in Belfast. While some allotment gardens are sited close to the city centre, the majority tend to be located in the suburbs or on the urban perimeter). In both cities there are long waiting lists to get access to allotment sites (Tables 1 and 2).

Data collected on public sites were supplemented by data collected on private sites provided in and around the two cities, and by data gathered at a community garden site, Suffolk in West Belfast, which is located in an interface area where Protestant and Catholic communities remain almost wholly segregated.

The second phase of research commenced with a broad sweep of practices in each city to contextualise the study. Sites suitable for data collection were selected, and multiple fieldtrips conducted to secure access, build rapport and identify prospective respondents. Sites were mapped and photographed, and extensive field notes were compiled. During the second phase of data collection, 48 interviews were completed in Dublin and 27 interviews were completed in Belfast. Interviewees were primarily drawn from the ranks of plot holders, with additional inputs from allotment activists and relevant members of local municipalities. Analysis of data is ongoing and utilises the method of constant comparison (Glaser and Strauss 1967). The case-study-based approach was adapted as an optimal means of elucidating the potential of UA to generate a shared politics of place on the ground in the contemporary city. 
Table 1. Public provision of allotments in Dublin city and county (population: 1,273,069 (Census 2011)).

\begin{tabular}{lc}
\hline Allotment site & No of plots (approx) \\
\hline Tymon Park & 13 \\
St. Anne's Park & 90 \\
Corkagh Park & 37 \\
De Courcey Square & 25 \\
Mount Anville & 100 \\
Turvey & 250 \\
Mill Lane Palmerston & 73 \\
Friarstown, Tallaght & 132 \\
Powerstown, Blanchardstown & 250 \\
Skerries, North Dublin & 150 \\
Current total provision by city councils & 1120 \\
\hline
\end{tabular}

\section{Cultivating sociality and social levelling on allotment sites}

There is a certain tension inherent in allotment gardening in terms of their legal, physical and normative publicness/privateness. In terms of their spatial distribution allotments are frequently located in interstitial or peripheral places in the city. While nominally public in terms of location (generally provided on public lands), they exhibit tendencies towards privatisation as evident in their weak visibility to the public-at-large, difficulties of access and security concerns. Security is an issue on both Belfast and Dublin sites. Respondents in Belfast informed us that there are strict rules about sites being locked at all times to ensure everyone's safety. Sites have to be secured on entering because there is residual conflict in the city and tensions remain high. Similarly, in Dublin allotment holders are issued with keys to the sites and are expected to secure access point on entry and egress.

Municipal allotments are provided on public lands, or on private lands leased by the authorities. As such, they constitute a public good in which all tax payers and citizens have a stake. As a resource held in public trust they are potentially open to all. In terms of social practices, however, allotments are at least semi-privatised through gated access, boundary creation and maintenance, and formal tenant/landlord arrangements. They require payment of a fee, however nominal, which constitutes a further barrier to entry. Some are characterised by contingent status, but all limit security of tenure through an 11-month leasing system. Every year, allotment holders have to re-apply for their sites. Furthermore, waiting lists for allotments indicate that supply exceeds demand and that access is therefore limited for prospective plot holders. Newer allotment sites are being

Table 2. Public provision of allotments in Belfast City (population 280,962 (Census 2011)).

\begin{tabular}{lc}
\hline Allotment site & No of plots (approx) \\
\hline Annadale & 92 \\
Ballysillan & 74 \\
Belmont & 57 \\
Blythefield & 26 \\
Musgrave & 19 \\
Whiterock & 10 \\
Current total provision by city council & 278 \\
\hline
\end{tabular}


provided on private lands on the city perimeter, particularly in Dublin. Here tenancy is also limited, and the cost of renting a plot is not subsidised but rather is set by market demand.

Once access is gained, allotments provide an arena for socialising and sociality. They enable individual and collective cultivation, exchange and dissemination of knowledge. They are spaces that are conducive to lingering, and allow for plot holders to be individually busy and active, and to interact with one another (the opposite of the case in an internet café). They are also sites of production and exchange which explicitly eschew a cash nexus. In that specific sense they form part of a collective commons, a productive space that exists between the market and the state. A key feature of the allotment sites in Dublin and Belfast is their facilitation of opportunities for social mixing and interaction with unknown others. People join together in a common understanding, with a shared concern for cultivation in a designated space. They act in concert despite the fact that they bring with them "multiple geographies of affiliation" and may only have "fleeting encounters with strangers" on site (Amin 2010, p. 4):

That is the huge potential of allotments, the sense of bringing people together. I really feel that. I have seen that countless times. Out there, there are no boundaries or no barriers. It is a great social mixing place. Now more people on neighbouring plots might get to know each other because there are no walls or fences like there are with gardens. Every plot almost merges into the next. (MF, DN, 082009)

One plot holder in Belfast explained that allotment space allows people to move beyond parochial understandings of their lives and the constraints of institutionalised sectarianism. His own efforts to promote allotment gardening, particularly for men, are intended to give people a sense of private ownership and control of a space albeit in the public realm:

they could come in their own time, they could come in the evenings, you know, they could come on Sundays, whenever, and they had an ownership of it ... so if they had one of these wee beds they could come up and own it, look after it, in their own time, and simply talk to people and break down barriers that were there for so long. (CH, BT, 30052013)

Elsewhere in the interview the respondent referred to the possibility of "softening" attitudes even among those older plot holders who held entrenched political views. Significantly, politics are not generally discussed on sites. Most respondents were adamant that such subject matter was effectively out of bounds, not permitted under the tacit rules of engagement (see below). Rather, the attitude softening might be the unintended consequence of working in harmony with others in a shared space with a defined, avowedly non-political, practical goal: land cultivation. Busy professionals who live relatively compartmentalised lives testify to the elective affinities that are generated purely as a result of cultivating an allotment alongside unknown others. As one female plot holder based in Belfast explains allotment cultivation is a total contrast to her scheduled and highly structured work life:

... this is like a free flowing and I like that. It's a social thing on one level, and I mean the man whose working here beside me, he's been working there since the year I was born and his company has been very stimulating. He's really into this on a very deep level. I see him carrying his little plants and he sows like it's a sacrament ... and then there's all the guys around here who are good craic. (GX, BT, 082012)

The absence of physical boundaries (walls) and the creativity associated with designing, managing and maintaining one's plot facilitates the construction of "a peopled-landscape" 
(Viljoen and Wiskerke 2012) which provides an opportunity to meet with and interact with others, and generate a sense of belonging. As noted earlier, allotment gardens are frequently located on the city perimeter, or if within the city boundaries, in interstitial places. They constitute terrain not at the centre, but on the edge. As Sennett has observed this very edge-like quality is precisely where "one community, one difference, meets another" (Sennett 2011, p. 396). In this context, allotment holders observe a form of presentation of self in which particularities are eschewed in favour of a common identity focused purely on the activities associated with working the land. Allotments are perceived by those who frequent them as a social leveller. Plot holders eschew divisions based on class and status, and insist that social categorisations are left at the gate. As one woman on a Dublin allotment site explains:

We've got guards [police officers] here... We've civil servants. You've bank managers. You've people unemployed. From all walks of life. And when you're up here in your wellies full of muck it doesn't matter who you are. You're the same. Everybody's the same. When we walk in that gate, we're all the same .... it gives you the excuse to come out and meet others without having to prove yourself, explain yourself, what you do for a living. It doesn't matter what car you drive, what kind of home you have, and what you do for a living. When you come in that gate, you're the same, we're all the same and everyone treats each other that way ... it's a leveler that's what it is, and you can come up here and destress, lose yourself for hours and meet wonderful, wonderful people you wouldn't have ever met out on the street. (DX, DN, 2013)

Another Dublin plot holder reiterates this point observing that symbolic markers of class and status are rendered irrelevant when people are engaged in the task of cultivation:

You're up there in your working clothes, there's no symbols of wealth as such. There are no suits. You know there's no people dressed in their good clobber. You're in there with your spade and your veg and it kind of... it's a neutralising environment where you wouldn't feel threatened by talking to another person. (FN2, DN, 2009)

Similarly, on the sites in Belfast there is also an explicit recognition that the allotments are not an exclusively working class preserve. People recognise that they attract people from different social classes as well as different communities in the city. This is significant in the context of Belfast where so much of public space tends to be inscribed with ethnonational territorial claims and, as a consequence, is effectively proscribed for those who do not share those claims.

there's people from both communities here, absolutely, and people from different social strata as well. (BX, BT, 07062013)

It [the allotment site] completely disregards your class, your religion. It's just about growing, that's what brings people here. (RX, BT, 062013)

Well, there's all walks of life up here. That's what it's all about. There's men and women from all backgrounds and everyone mixes ... You've some Chinese people here too and we gave them a bit of a dig out and got a wee thing going, like to make them feel welcome and that you know. (GI, BT, 062013)

On the allotment site the problem of how strangers express themselves to each other is solved through a focus on applying knowledge, skill and physical labour. The terrain sets the boundaries to interaction. In both Dublin and Belfast respondents reported that 
in general the sociality they experience on site does not extend beyond the site. Their pre-existing group affiliations and sociability circuits remain relatively separate from the allotment site. In other words, people who share this public space and engage in rites of co-operation and sociability with others tend not to continue those social relations once off site. Encounters with others are primarily about civil interfacing, rather than creating lasting or deep attachments. Sennett has written of how disparate groups might make use of theatrical language and role play as a basis for a common speech "which creates an 'as if' as though they are in the same realm" (2011, p. 395). Plot holders, intimately connected to the material practices of cultivation, privilege that version of themselves above all other as a means of creating a common ground with unknown others. It is all about the doing, the getting on with the practical task of cultivation. But this practice necessarily draws them into circuits of sociality as well as shared knowledge. These exchanges produce "vivacity" in the public space of the allotments.

Allotments facilitate the striking up of easy interactions between plot holders. They are places where strangers seem less strange since there is a shared commitment to cultivation:

When I'm coming for four hours I'll always bring me flask and if someone was around I would say do you want a cup of tea, they might take it and they mightened take it. (FN1, DN, 2009)

There is a sense of fellowship connected to the joint project even if each plot holder is in effect engaged in an individual enterprise. A premium is placed on the willingness and capacity to share the place with others. In East Belfast, one respondent fondly recalled the words of a long standing plot holder:

Old Colin used to say if you don't have time to sit down in the communal shed and have a cup of tea with your fellow allotment holders, then you shouldn't be here. (GI, BT, 062013)

Activists in particular are keen to stress the potential of allotments as social levellers:

Allotments should not be a refuge for retired males. I thought that families should have access
to them, I thought that young couples should have access to them. They should be available to
all ... irrespective of employment status, age that families should have access, special groups-
mental health groups should have access. I have been arguing for multi use. (MF, DN, 092009)

For advocates the allotment landscape acts as an important resource in the city that facilitates social interaction. They see that UA can offer the contemporary urban dweller an opportunity to reconnect with the land but, crucially, to connect with other social actors. For plot holders, the spatial layout and in particular the absence of physical boundaries (omission of walls) facilitates, promotes and enhances the construction of a sense of belonging to the place. As two women plot holders in Dublin note:

Well I bought my apartment in the height of the boom and paid a fortune for it, and although I have a balcony, it's really not enough. I grew up here (in the area) and my parents had a large garden and I didn't realise how much I'd miss having a garden until I bought my own home ... . I like coming here and a lot of the time I'd sit and read or potter around in the shed, tidy it up and do little odd jobs .... oh I love the company here. I absolutely love it. There's $\mathrm{x}$ down there, and y here beside me and we're all great buddies. (KX, DN, 2013)

Well I just had to have one. The minute I saw this [site] opening I was down in a shot... ..you've no room in the new apartments and like you've the park there for a walk and that's ok if you've a dog and you'd go walking regularly, but it's pretty lonely going on your own 
all the time. I do go, and I love it but here, here I can have a chat, do a few bits and basically just enjoy the open air. (HX, DN, 2013)

The physical reconfiguration of Dublin in the years of the economic boom created new modalities for living to which Dubliners continue to adjust. Apartment living is a relatively new phenomenon in the city and here we see how people respond to the challenges which this new kind of living engenders. A patch of land for cultivation re-grounds them, providing recreational access to the outdoors, an opportunity to grow food for consumption and a version of shared public space that is not available in the context of privatised apartment living.

\title{
Moving beyond ethno-national divisions
}

We have already alluded to the problem of Belfast as a divided city. Ethno-national divisions are inscribed in the cityscape in very public ways. Indeed, "the longevity of communal territories and their boundaries and of the struggles to control them is testimony to the enduring significance of sectarian territoriality in Belfast" (O'Dowd and Komarova 2009, p. 7). Remarkably, such demarcations are noticeably absent from the allotments spaces. Allotments offer a space where people can interact without having to be conscious of or adhere to prescribed ethno-national distinctions. What stands out is the neutrality of these spaces in a city with markers of identity at every turn and where interface barriers are designed to "police" divisions between the two main communities.

On allotment sites, manifestations of religious or political views are frowned upon. Respondents maintain that religious views or political opinions are completely irrelevant in the context of shared cultivation of land:

\begin{abstract}
No, no .... they wouldn't talk about religion. No. You know, nobody really knows what religion you are .... it's a neutral kind of eh ... there never any question whether you're [coughs] .... the sole interest is the allotment, and our conversation revolves around that, and that's it. No, no one would ever speak of anything like religion ... you're not interested in any of that carry-on in here. (JK, BT, 062013)
\end{abstract}

I know more people on this allotment in four weeks than I do living on my street for eight years. If you don't feel like being friendly you can just hide in your shed but you wouldn't do that. No one talks about any of that stuff in here ... I've never been asked about my political opinions or that, and I do not think it's really anything people would bring up to be honest. I really don't think people would be bothered with that in here. (IC, BT, 062013)

In general, politics cannot be discussed on the site as there is a latent fear that one could all too easily antagonise people. One plot holder who had previously worked for the prison service observed that:

you don't discuss your background, and I certainly can't get into any conversations about that here, with my background. (GG, BT, 2013, emphasis added)

This capacity to bracket difference, even temporarily, is relatively novel in a divided city such as Belfast. Plot holders are entering a public space and discarding the particularities of their identities - class, gender, ethnicity, religion, political affiliation. In effect, the allotment site constitutes a public realm which enables plot holders to transcend distinction and difference and move beyond self-interest (Arendt 1958). They enter into "a community of 
equalization of speech in which self-reference is a violation of the norms of politics" (Sennett 2011, p. 396). Through the application of this tacit rule of engagement a new politics of place is thus opened on the allotments. The allotment space provides a level playing field, enabling the dissolution of an ethno-national configuration and its replacement by a community of growers, whose raison d'etre derives literally from ground-up cultivation:

Well everyone is just all one, and we just all work together here. Everyone is all one, we all teach each other and share what we know .... there's none of that nonsense in here ... everyone's all one in here .....I've met people from different creeds and from different parts of Belfast and I never had trouble with any of them. (FX, BT, 07062013)

A number of initiatives are underway in Belfast to create opportunities for disadvantaged young people and ex-prisoners to become involved in UA. This mirrors similar initiatives undertaken in Dublin, albeit that the context is much less politicised than in the North. It is noteworthy that some respondents in Belfast were hesitant about the rehabilitative possibilities that allotments might be required to sustain. For some, social mixing is all very well when people share the same broad class categories and hail from what they perceive as the law-abiding sections of the ethno-national communities. Such respondents who reject overt political violence have their doubts about integrating people who "had not kept their noses clean", that is, people who had been involved in political or paramilitary activities. There is a fear that the presence of this "other" on the site might lead to a disengagement of existing plot holders. When asked about their openness to potential plot holders who "had a past" they were equivocal:

It's hard to ... I mean in the interest of, like I rarely come in here to the shed and I usually stay up on my own allotment, but I would certainly exchange the time of day with them, and I certainly wouldn't be antipathetic. Plus, I would be watching for a trend, to make sure that they kept their nose clean and that we didn't have unintended consequences. (GI, BT, 062013)

The legacy issue of the Troubles cannot be easily erased as another respondent observed:

Oh well, I found that over a long, long time because if you live for maybe 30 or 40 years and your life depends on either keeping your mouth shut or keeping your head down or making sure you're in the right place, even though things have changed, there would be a residual wariness. (GI, BT, 062013)

While generally the majority of plot holders are deemed to leave their politics at the gate, there is concern about how making one's political views known, particularly if they were deemed to be antagonistic to one community or the other, could destabilise the tacit rules of engagement. Nevertheless, respondents are adamant that most plot holders conform to the social requirements:

The vast majority of people are ordinary decent people who you could trust your life with, borrow their bits, could get advice, you'd get assistance and there'd be no hassle, and you'd be quite comfortable, a chat and go on ahead, and all would be well. (GI, BT, 062013)

But crucially, they observe that the kind of integration that occurs on the allotments is organic rather than prescribed. They believe that any forced attempt to, for instance, apply quotas to the numbers from different ethno-national communities in the allotment allocations policy would be doomed to failure. The beauty of the allotments is that the 
prime focus is on the love of the land for its own sake. The commitment to cultivation pushes all other identifying markers into the background, rendering them less salient and demonstrating through practice the possibility of integrating different communities. Several respondents recounted small acts of unforced kindness. A Catholic plot holder commented on the generosity of her neighbours when she had to leave her site in Belfast for several weeks while her sister was terminally ill in Dublin:

They all got together and looked after it, and I choke up when I think of that...., so that I wouldn't lose it [the plot]. A couple who subsequently moved to the plot next to me, and a woman up there and another couple ... I didn't know their names..and they were Protestants too, and I was very touched by that. (GX, BT, 082012)

An ex-paramilitary saw allotment gardening as a means of moving on from a past which had involved him in conflict and sectarian violence. The allotment constitutes a refuge, a place away from home that affords the prospect of low intensity sociability. He repeatedly spoke of it as a place which offers "peace of mind". His view is that:

the allotment helps the kids see a different way forward, away from all the sectarianism that's going on. (TX, BT, 062013)

From this perspective, the ethno-national conflict sits firmly in the past, and the allotment provides a template for how to get on and grow together. Respondents accept that there are differences between people - political, religious and cultural - but suggest that these differences can be transcended:

... you have to tolerate that, we're all different here, and you just have to get along. (TX, BT, 062013)

Well my attitude is that success in Northern Ireland is measured in small amounts, and you know it's been analyzed to death and this is why I can't be bothered with things like that and here I think the majority of people feel the same .... They're here to grow vegetables and socialize, regardless of where you are from. People just want to move on, so it's a measure of how well things have moved on. (GG, BT, 2013)

The nature of agricultural productive work which requires both individual enterprise and collective responsibility creates a very visceral imperative "to get along".

Lownsbrough and Bunderman have documented the particular qualities associated with good public space. They argue that a constellation of "spaces of potential" have emerged in recent years with the potential to sustain and increase interaction in public space (2007, p. 19). This comparative study of allotment gardening in two cities - Dublin and Belfast - provides an opportunity to test whether UA can act as a "space of potential" wherein social or ethno-national cleavages might be managed, challenged and/or transcended. We have demonstrated the extent to which UA as a practical activity can engender co-operative responsiveness to others on their own terms, (Sennett 2012, p. 6). We argue therefore that the kind of civil disaffiliation associated with privatisation and marketisation in late capitalism is not inevitable. Contrary to what is often assumed urbanites (and suburbanites) may exhibit a strongly developed sense of place attachment and belonging, that overcomes even if only temporarily - class and ethno-national differences. As we have demonstrated this is evidenced in the orientations and practices of plot holders in the context of allotment gardening in the cities of Dublin and Belfast. They overtly challenge those forces which 
may undermine a sense of shared public space: in Belfast, the heightened sensitivity about ethno-national territoriality and in Dublin the valorisation of social class differences. Just as places may become non-places over time, it is also possible that non-places may be refashioned as places that are both meaningful and functional within the urban vernacular. Eizenberg (2012) points to the community garden in New York City as an example of an alternative modality of social reproduction that takes after the model of the commons. We suggest that the urban allotment is a significant "space of potential" in the twentyfirst century. Urban allotments have a long and chequered history but their recent revival speaks to demand for a form of civil interface or affiliation that counteracts the deleterious effects of privatisation, marketisation and placelessness. Moreover, we have shown that allotments constitute a particular localised form of public space that can play a crucial role "in providing a focus for practical solutions that increase our sense of society and mutuality" (Lownsbrough and Beunderman 2007, p. 3).

\section{Conclusion}

This paper set out to explore UA as a particular and localised instance of a "shared politics of place", and sought to demonstrate the potential of UA activities to generate civic and social dividends for participants. Specifically, the paper focused on the experiences of plot holders in the city of Dublin where daily life has been overshadowed by austerity policies since 2008. Austerity succeeded a period of intense financialisation of everyday life. We also focused on plot holders in post-peace process Belfast, a city still coming to terms with the ethno-national divisions that shaped its past. The paper drew on extensive qualitative data gathered in both cities to demonstrate the centrality of allotment cultivation to the creation of shared-in-common places. Public space, far from being marginal space in the city, can be defined by its centrality to the city's life world. Ideally, individuals and communities create and sustain civil interfaces where barriers are dismantled, knowledge is exchanged, stereotypes are challenged, empathies are generated and where people get on with the business of simply getting on with their lives. As we have demonstrated, this is how allotment gardening works in both contexts, predicated on a willingness to disregard social and ethno political categorisations once on site. This is not to deny that such differences exist, and that they are salient beyond the allotment gates. However, in the cultivation practices that prevail on the allotments sites a degree of co-operation and civil integration is generated in the sense that plot holders become engaged in "the acquisition and routinization of everyday practices for getting on with others in the inherently fleeting encounters that comprise city life" (Vertovec 2007, p. 4). UA in the city has the potential to reinvigorate sites that are unused or underutilised, to green brown fields, to create sustainable models of growth and development and to revive the public realm at the heart of the city.

O'Dowd and Komarova report that it is easier to secure a measure of cross-community agreement in Belfast on issues that involve making decisions about space with less determinate boundaries $(2009$, p. 6). Allotments are relatively open spaces that proffer the opportunity to engage in a politics of shared place. This is relatively novel in the context of Belfast, and also to some extent in Dublin, a city that is highly socially segregated in terms of social class. According to Sennett (2012) living with difference - racially, ethnically, religiously or economically - is the most urgent challenge facing civil society today. Sennett argues that it is imperative that we move beyond tribalism in the modern city, and take up the challenge of evolving co-operative relations with unknown others. But this task is made all the more difficult because modern society has been de-skilling people in the practice of co-operation. The practical activity of land cultivation which links us back to 
the rural past and addresses some of the environmental challenges of the present offers a template for reform. Working the land not just as individuals but as cooperating partners with unknown others points the way ahead towards a new "geography of acceptance" (Massey 1995, p. 74) in cities of the Global North.

\section{Acknowledgements}

The authors would like to thank the two anonymous referees for their helpful comments.

\section{Disclosure statement}

No potential conflict of interest was reported by the authors.

\section{Funding}

This work was supported by a doctoral research scholarship from the Irish Research Council.

\section{Note}

1. The COST Action TD 1106 Urban Agriculture Europe was established in 2012 and runs until 2016. It includes researchers and practitioners from more than 20 European countries. The objective is to elaborate a European perspective on Urban Agriculture and its potentials for sustainable development according to the Europe 2020 Strategy.

\section{References}

Amin, A., 2010. Living with diversity: for a politics of hope without fear. A manifesto for another Europe. Barcelona: Forum of Concerned Citizens of Europe.

Arendt, H., 1958. The human condition. Chicago: University of Chicago.

Baumann, G., 1996. Contesting culture: discourses of identity in multi-ethnic London. Cambridge: Cambridge University Press.

Binns, T. and Lynch, K., 1998. Feeding Africa's growing cities into the 21st century: the potential of urban agriculture. Journal of International Development, 10 (6), 777-793.

Bryan, D., 2009. Negotiating civic space in Belfast. Divided cities/contested states. Belfast: Queen's University, 1-17, Working Paper No. 13.

Clausen, R., 2007. Healing the rift. Monthly Review, 59 (1), 1-12.

Crouch, D., 1989. The allotment: its landscape, and locality: ways of seeing landscape and culture. Area, 21 (3), 261-267.

Eizenberg, E., 2012. Actually existing commons: three moments of space of community gardens in New York City. Antipode, 43 (3), 764-782.

Glaser, B. and Strauss, A., 1967. The discovery of grounded theory: strategies for qualitative research. Chicago: Aldine.

Hampwaye, G., Nel, E., and Ingombe, L., 2009. The role of urban agriculture in addressing household poverty and food security: the case of Zambia [online]. GND Working Paper Series, FANRPAN. Available from: http://www.gdnet.org [Accessed 8 January 2014].

Howard, E., 1965. Garden cities of tomorrow. Cambridge: The MIT Press.

Jacobs, J., [1961] 1992. The death and life of great American cities. New York: Vintage.

Karantasai, E., 2011. Transcultural gardens - a proposal for exploitation of urban voids as intensively productive land and as a method of integration of urbanization of minorities: case studies demonstrating design tools and managing methodology. In: M. Behassi, S.A. Shahid, and J. D'Silva, eds. Sustainable agricultural development: recent approaches in resource management and environmentally-balanced production enhancement. New York: Springer, 125-138.

Kortright, R. and Wakefield, S., 2011. Edible backyards: a qualitative study of household food growing and its contributions to food security. Agriculture and Human Values, 28 (1), 39-53. 
Lofland, L., 1973. A world of strangers: order and action in urban public space. New York: Basic Books.

Lownsbrough, H. and Beunderman, J., 2007. Equally spaced? Public space and interaction between diverse communities. London: Demos.

Madden, D., 2010. Revisiting the end of public space: assembling the public in an urban park. City and Community, 9 (2), 187-207.

Massey, D., 1995. The conceptualization of place. In: P. Jess and D. Massey, eds. A place in the world? Places, cultures and globalization. Oxford: Oxford University Press, 45-86.

Moselle, B., 1995. Allotments, enclosure and protletarianization in early nineteenth-century Southern England. The Economic History Review, New Series, 48 (3), 482-500.

Mougeot, L.J.A., 2005. Agropolis: the social political and environmental dimensions of urban agriculture. London/Ottawa: Earthscan/IDRC.

Mougeot, L.J.A., 2006. In focus: growing better cities. Urban agriculture for sustainable development. Ottawa: IDRC.

Moulin-Doos, C., 2014. Intercultural gardens: the use of space by migrants and the practice of respect. Journal of Urban Affairs, 36 (2), 197-206.

Muller, C., 2007. Intercultural gardens, urban places for subsistence, production and diversity. German Journal of Urban Studies, 46 (1), 1-6.

O'Dowd, L. and Komarova, M., 2009. Regeneration in a contested city: a Belfast case study. Divided cities/contested states [online], Working Paper No. 10, 1-30. Available from: www.conflictincities. org [Accessed 2 August 2014].

O’Dowd, L. and McKnight, M., 2013. Urban intersections: religion and violence in Belfast. Space and Polity, 17 (3), 357-376. doi:10.1080/13562576.2013.850823

Oldenburg, R., 1989. The great good place. New York: Paragon House.

Premat, A., 2005. Moving between the plan and the ground: shifting perspectives on urban agriculture in Havana, Cuba. In: L.J.A. Mouget, ed. Agropolis: the social and environmental dimensions of urban agriculture. London/Ottawa: Earthscan/IDRC, 153-186.

Punch, M., 2005. Problem drug use in the political economy of urban restructuring: heroin, class and governance in Dublin. Antipode, 37 (4), 754-774.

Rigney, P., 2012. The impact of anti-crisis measures and the social and employment situation: Ireland [online]. Dublin: Irish Congress of Trade Unions European Economic and Social Committee Workers' Group. Available from: www.ictu.ie [Accessed 5 March 2014].

Robins, K., 1993. Prisoners of the city. In: E. Carter, J. Donald, and J. Squires, eds. Space and place: theories of identity and location. London: Lawrence and Wishart, 303-330.

Sanjek, R., 1998. The future of us all: race \& neighbourhood policies in New York City. Ithaca, NY: Cornell University Press.

Sassen, S., 2013. Expulsions: the fifth circle of hell. Inaugural lecture in the Trinity College DublinUniversity College Dublin Sociology Public Lecture Series. Lecture delivered at Trinity College Dublin, on January 13, at 8pm GMT.

Sennett, R., 1970. The uses of disorder: personal identity and city life. New York: Knopf.

Sennett, R., 2005. Civility. Urban Age Bulletin, 1 (Summer), London: Cities Programme at the London School of Economics, 1-3.

Sennett, R., 2011. Reflections on the public realm. In: G. Bridge and S. Watson, eds. The new Blackwell companion to the city. Somerset, NJ: John Wiley, 391-397.

Sennett, R., 2012. Together: the rituals, pleasures and politics of cooperation. New Haven: Yale University Press.

Smit, J. and Nasr, J., 1992. Urban agriculture for sustainable cities: using wastes and idle land and water bodies as resources. Environment and Urbanization, 4 (2), 141-152.

Tornaghi, C., 2014. Critical geography of urban agriculture. Progress in Human Geography [online]. Published online 5 February. doi:10.1177/0309132513512542. Available from: http://phg. sagepub.com/content/early/2014/02/04/0309132513512542, 1-17 [Accessed 1 September 2014].

Vertovec, S., 2007. New complexities of cohesion in Britain: super-diversity, transnationalism and civil integration. Wetherby, UK: Commission of Integration \& Cohesion, Communities and Local Government.

Viljoen, A. and Wiskerke, J.S.C., eds., 2012. Sustainable food planning: evolving theory and practice. The Netherlands: Wageningen.

Warner, S.B., Jr., 1987. To dwell is to garden: a history of Boston's community gardens. Boston: North Eastern University Press. 